\title{
22. MAGNETIC ANISOTROPY AND SOME OTHER MAGNETIC PROPERTIES OF SERPENTINIZED PERIDOTITES FROM ODP HOLE $670 \mathrm{~A}^{1}$
}

\author{
M. Mansour Bina, ${ }^{2}$ Bernard Henry, ${ }^{2}$ and Mathilde Cannat ${ }^{3}$
}

\begin{abstract}
Magnetic fabrics of serpentinized peridotites are related to anisomorphic magnetite formed during serpentinization. In the less serpentinized facies they are, however, mainly mimetic of the high temperature deformation prior to serpentinization. In more serpentinized peridotites, the magnetic fabrics, related to magnetite veins which are more developed in this case, are superimposed on mimetic fabrics. Remanent properties, hysteresis loop parameters, and Curie temperatures were measured. Natural remanent magnetizations (NRM) have crystallization remanent magnetic (CRM) origin. Measured magnetic parameters suggest that pseudo-single domain (PSD) grains of magnetite are present in samples with low degree of serpentinization. The samples with high degree of serpentinization contain mainly multi-domain (MD) magnetite grains.
\end{abstract}

\section{INTRODUCTION}

Serpentinized peridotites, having originated from hydration of upper mantle peridotites, were drilled during Leg 109. Serpentinization is supposed to occur below $500^{\circ} \mathrm{C}$ (Cann, 1979; Francis, 1981) giving rise to the formation of magnetite crystals in the Earth's magnetic field, and thus to the acquisition of CRM. Strong magnetic fabrics have been reported for ultramafic rocks from oceanic crust (Smith and Banerjee, 1985). This paper reports on magnetic properties, and particularly on the anisotropy of some drilled samples.

\section{EXPERIMENTAL PROCEDURES}

Fifteen samples have been studied here, eight with orientation (top and bottom). Except as noted below, the method and techniques used here are the same as described in "Magnetic Properties of Basalts from Hole 648B" (Bina, this volume). Magnetic susceptibility anisotropy was measured using a torque-magnetometer (Daly and Formont, 1969).

Magnetic anisotropies of remanent magnetizations were studied on the eight oriented samples following the same procedure. Remanent magnetization, acquired successively in six different directions (after demagnetization by alternating field), was measured using a JR4 spinner magnetometer. For this study, a sample holder was constructed for anisotropy studies of anhysteretic remanent magnetization (ARM) and saturation isothermal remanent magnetization (SRM). A large space alternating field (AF) laboratory-made apparatus, with an appropriate DC coil, was used for ARM acquisition. SRM was obtained in a steady field of 8000 Oe using an electromagnet. From these six values, the best fit anisotropy tensor has been calculated. Theoretical values of remanent magnetization from this tensor were compared with the measured ones; in all cases, the difference between the measured and calculated values was found to be very small, showing clearly that for these relatively strong anisotropies, measurements in six directions are sufficient to obtain precise results. We have calculated extrapolated saturation values of ARM (see magnetic properties section) to determine the ARM fabric.

${ }^{1}$ Detrick, R., Honnorez, J., Bryan, W. B., Juteau, T., et al., 1990. Proc. ODP, Init. Repts., 106/109: College Station, TX (Ocean Drilling Program).

${ }^{2}$ Laboratoire de Géomagnétisme du Parc Saint Maur, Université Paris 6 et Centre National de la Recherche Scientifique.

${ }^{3}$ Laboratoire de Petrologie, Université de Bretagne Occidentale.

\section{MAGNETIC FABRICS}

The very few studies carried out on magnetic anisotropy of ultramafic rocks from oceanic crust (Smith and Banerjee, 1885; MacDonald and Ellwood, 1988; F. Hrouda, pers. comm.; Rochette, pers. comm.) and some indications of our shipboard measurements relative to NRM inclinations suggested to us the probable existence of relatively strong anisotropy in these rocks. In order to study the magnetic fabric of the different magnetic grain families, three different approaches have been used.

The first one consists in the classical determination of susceptibility anisotropy in low field (Graham, 1954; Daly, 1970; Hrouda, 1982), which integrates the effects coming from all the minerals of the rock, that is from dia-, para-, and ferrimagnetic components; however, owing to the high concentration of magnetite in our samples, ferrimagnetics probably have here a strongly dominant effect in the total anisotropy.

The two other approaches are based on the determination of anisotropy of remanent magnetizations (Daly, 1970; Daly and Zinsser, 1973; Biquand, 1982; MacCabe et al., 1985): ARM (which is mainly carried by the smaller grains; King et al., 1982) and SRM.

Table 1 shows that strong differences exist between the magnetic fabrics determined by the three methods. In particular, for nearly $25 \%$ of the anisotropy measurements, large differences in orientation exist between same name axes (maximum, intermediate, or minimum) from the three fabrics. Here ARM anisotropy always has the highest anisotropy percentage, showing that magnetite grains, which carry the ARM, are the most anisomorphic. Five of the eight samples show oblate ( $f<0.5$ ) magnetic fabrics.

For the less serpentinized samples, the fabric of the crystallographic axes of olivine (and of orthopyroxene for Sample $670 \mathrm{~A}-6 \mathrm{R}-1,4-6 \mathrm{~cm}$ ) and the orientation of the high temperature spinel foliation have been determined (see Cannat et al., this volume). The preferred orientation diagrams (Fig. 1) show that during the plastic deformation of the peridotites, the slip direction in olivine was the crystallographic axis [100]. This axis falls close to the spinel lineation of each sample (marked by the elongation of the spinel grains). The slip planes in olivine were perpendicular to the crystallographic axis [001] and/or [010]. These axes constitute girdles close to perpendic- 
Table 1. Magnetic fabrics in Hole 670A: $\mathrm{h}$ is the anisotropy percentage: $h=100 *\left(v_{1}-v_{3}\right) / v m$ (where $v_{1}, v_{2}$, and $v_{3}$ are the principal values with $v_{1} \geqslant v_{2} \geqslant v_{3}$, and $\mathbf{v m}$ their mean value). $f$ is a shape parameter: $f=\left(v_{1}-v_{2}\right) /\left(v_{1}-v_{3}\right)$ varying from 0 (oblate fabric) to 1 (prolate fabric). For each sample, declination axis D is defined relatively to an arbitrary coordinate system, and inclination axes with respect to horizontal plane.

\begin{tabular}{|c|c|c|c|c|c|c|c|}
\hline \multirow[b]{2}{*}{ Sample } & \multirow[b]{2}{*}{ Fabric } & \multirow[b]{2}{*}{ h } & \multirow[b]{2}{*}{ f } & \multicolumn{2}{|c|}{$\begin{array}{l}\text { Maximum } \\
\text { axis }\end{array}$} & \multicolumn{2}{|c|}{$\begin{array}{l}\text { Minimum } \\
\text { axis }\end{array}$} \\
\hline & & & & D & I & D & I \\
\hline \multirow[t]{3}{*}{$3 \mathrm{~W}-1,12-14$} & Susc. & 14.9 & 0.24 & 314 & 46 & 206 & 18 \\
\hline & SRM & 16.4 & 0.17 & 343 & 54 & 195 & 31 \\
\hline & ARM & 26.7 & 0.26 & 69 & 51 & 204 & 30 \\
\hline \multirow[t]{3}{*}{$5 R-1,55-57$} & Susc. & 18.3 & 0.51 & 266 & 79 & 102 & 11 \\
\hline & SRM & 17.2 & 0.61 & 325 & 65 & 97 & 17 \\
\hline & ARM & 51.6 & 0.51 & 254 & 55 & 104 & 31 \\
\hline \multirow[t]{3}{*}{$5 \mathrm{R}-1,114-116$} & Susc. & 10.8 & 0.74 & 348 & 53 & 80 & 1 \\
\hline & SRM & 14.1 & 0.78 & 335 & 52 & 140 & 38 \\
\hline & ARM & 23.2 & 0.87 & 353 & 56 & 101 & 13 \\
\hline \multirow[t]{3}{*}{$5 R-1,134-136$} & Susc. & 12.6 & 0.45 & 204 & 21 & 294 & 1 \\
\hline & SRM & 11.8 & 0.42 & 204 & 14 & 105 & 34 \\
\hline & ARM & 32.5 & 0.35 & 2 & 40 & 120 & 29 \\
\hline \multirow[t]{3}{*}{$5 R-2,55-57$} & Susc. & 15.4 & 0.11 & 79 & 19 & 299 & 66 \\
\hline & SRM & 14.5 & 0.34 & 102 & 19 & 338 & 58 \\
\hline & ARM & 37.4 & 0.34 & 240 & 9 & 342 & 51 \\
\hline \multirow[t]{3}{*}{$5 R-2,102-104$} & Susc. & 12.9 & 0.27 & 306 & 48 & 213 & 2 \\
\hline & SRM & 10.2 & 0.39 & 294 & 30 & 203 & 2 \\
\hline & ARM & 22.6 & 0.32 & 341 & 65 & 208 & 17 \\
\hline \multirow[t]{3}{*}{$6 \mathrm{R}-1,4-6$} & Susc. & 20.2 & 0.20 & 211 & 6 & 312 & 63 \\
\hline & SRM & 13.0 & 0.34 & 226 & 5 & 330 & 70 \\
\hline & ARM & (1277) & 0.22 & 123 & 34 & 18 & 21 \\
\hline \multirow{3}{*}{$8 R-1,31-34$} & Susc. & 7.1 & 0.19 & 17 & 6 & 121 & 67 \\
\hline & SRM & 8.1 & 0.50 & 232 & 31 & 91 & 53 \\
\hline & ARM & 13.3 & 0.62 & 63 & 19 & 309 & 49 \\
\hline
\end{tabular}

ular to the spinel foliation (marked by the flattening of the spinel grains). In orthopyroxene, the slip plane was (100): the [100] directions are close to perpendicular to the spinel foliation. Figure 1 gives the comparison between the crystallographic and magnetic fabrics.

1. In Sample 670A-5R-2, 102-104 cm, the three minimum axes are close to the spinel foliation plane and to the main cluster of [010] olivine axes, and the minimum-intermediate plane for ARM is not very different from the spinel foliation.

2. In Sample 670A-6R-1, 4-6 cm, there is a permutation of axes between the ARM fabric and the two other fabrics; the magnetic foliation for susceptibility and for SRM, and the maximum-minimum axes plane for the ARM are also close to the spinel foliation; the minimum axes for susceptibility and for SRM, and the intermediate axis for ARM have an orientation similar to the [100] orthopyroxene axes: they are thus close to perpendicular to the spinel foliation. The maximum axis for susceptibility and for SRM, and the minimum axis for ARM are close to the main cluster of the [100] olivine axes (that is, close to the spinel lineation).

3. In Sample 670A-8R-1,31-33 cm, which is more serpentinized, magnetic axes are more scattered and there is no simple relation with the spinel foliation, except for the maximum susceptibility axis, which is in the spinel foliation plane, close to the main cluster of the [100] olivine axes. In this sample, magnetite veins have a clear visible preferential orientation which closely corresponds to the magnetic foliation of SRM.

On the one hand, the magnetic fabrics (particularly for susceptibility and ARM) are therefore often related to the high temperature deformation structure in the rock: in such cases, the maximum axes (classically referred to as "magnetic lineation" and corresponding to the lengthening of magnetite particles) coincide with the [100] olivine axes (which is close to the tectonic lineation direction), the minimum axes (per- pendicular to the flattening of magnetite particles) are close to the [010] olivine, and [100] orthopyroxene axes (which are close to perpendicular to the spinel foliation), and some magnetic planes coincide with the spinel foliation plane; moreover, in these two samples, the NRM vector is close to the spinel foliation. On the other hand, in the more serpentinized sample, only the magnetic foliation of SRM is closely related to the orientation of magnetite veins. Owing to the fact that SRM seems here to be mainly carried by the larger magnetite grains (SRM values are strongly higher than ARM ones and NRM vector does not seem to be related to magnetite veins orientation; see also next section), one may assume that magnetite veins (Fig. 2C) are essentially formed by such grains, and that smaller grains are more dispersed (Dunlop and Prévot, 1982) and have a fabric rather mimetic (Fig. 2A, -B) of the structure associated to the high temperature deformation prior to serpentinization. This original result is preliminary since too few oriented samples have been obtained from Hole $670 \mathrm{~A}$

\section{OTHER MAGNETIC PROPERTIES}

NRM and, for some samples, the viscosity index were measured according to the Thellier and Thellier (1959) method. The index of viscosity $(v)$ varies from $3 \%$ to $11 \%$. Samples with high value of $v$ contain usually magnetic carriers with large grain sizes which have a lower stability. NRM intensities $\left(J_{n}\right)$ vary with the degree of serpentinization from 0.2 to $45\left(10^{-4} \mathrm{emu} / \mathrm{g}\right)$.

As magnetites are usually located largely along the veins, heterogeneity is one of the characteristics of these rocks. Stable inclinations are highly scattered (see paleomagnetic report in this volume). Susceptibility $(\chi)$ depends on magnetic concentration and on grain sizes (ranging from 1 to 41 in $10^{-4}$ emu/g Oe $)$. Koenigsberger ratio Q $\left(J_{n} / h \chi ;\right.$ with $h=0.4$ Oe at the site) is very low (1.04) compared to the basalts. Zijderveldt plot for AF demagnetization shows almost univectorial component for most of samples. The weak secondary magnetization seems to be soft viscous remanent magnetization (VRM) and/or partial thermoremanent magnetization (PTRM) acquired during cooling from serpentinization temperature to seafloor ambient temperature. The median demagnetizing field $\left(\mathrm{MDF}_{\mathrm{n}}\right)$ is inversely correlated to the degree of serpentinization. It seems that the size of magnetic carriers increases with the degree of serpentinization.

1. Measured hysteresis loop parameters are listed in Table 2. $\mathrm{J}_{\mathrm{s}}$ (induced saturation magnetization), which is proportional to the magnetic mineral content in the sample, varies from 0.2 to $7.4(\mathrm{emu} / \mathrm{g})$. Some high values of $\mathrm{J}_{\mathrm{s}}$ are larger than already reported values for serpentinized peridotites (Dunlop and Prévot, 1982; Smith and Banerjee, 1985). $\mathrm{J}_{\mathrm{rs}} / \mathrm{J}_{\mathrm{s}}$ which is an index of domain structure, ranges from 0.04 to 0.24 , for high degree to low degree of serpentinization. An inverse correlation is found (Fig. 3) for all the samples, between coercive forces (corrected for paramagnetism) and $\mathbf{J}_{\mathrm{s}}$ (denoted here as the magnetic mineral concentration and the degree of serpentinization). As generally, magnetite concentration increases with serpentinization, the finding trend suggests, as concluded from NRM study, large multi-domain (MD) magnetite grains contribute to the magnetization of the highly serpentinized samples while low degree serpentinized samples contain smaller grains, probably large pseudo-single domain (PSD) grains. However, both MD and PSD grains family are present in some samples as indicated by large values of $\mathrm{J}_{\mathrm{s}}, \mathrm{MDF}_{\mathrm{n}}$ and $\mathrm{H}_{\mathrm{c}}$ (e.g., $670 \mathrm{~A}-3 \mathrm{R}-1,12-14 \mathrm{~cm}$ ).

2. Thermomagnetic measurements: The Curie temperatures $\left(T_{c}\right)$ were measured for seven samples. The method of 
ORTHOPYROXENE

SAMPLE :

A)

B)

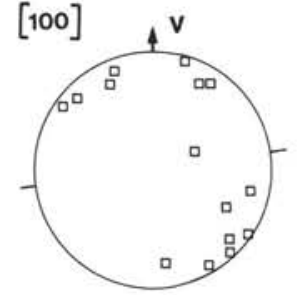

C)
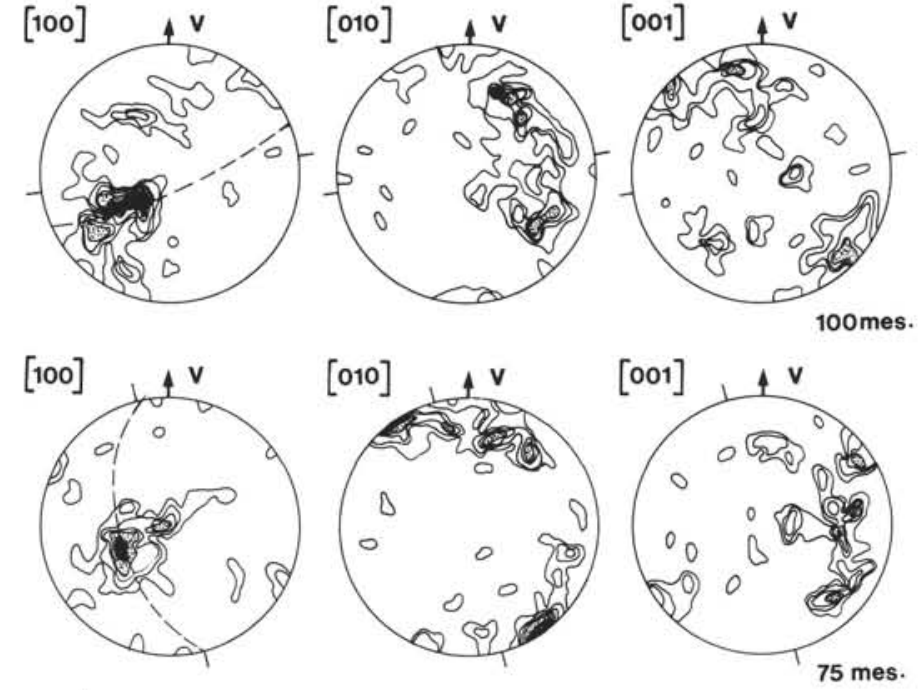

MAGNETIC FABRICS
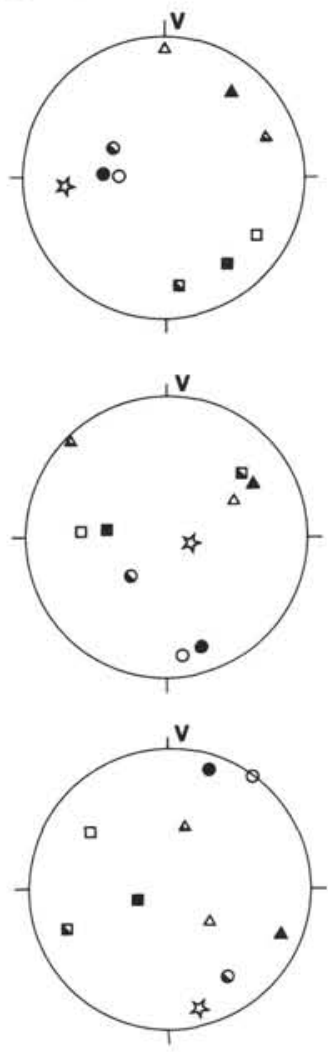

Figure 1. A. Sample 670A-5R-2, 102-104 cm. B. Sample 670A-6R-1, 4-6 cm. C. Sample 670A-8R-1, 31-33 cm. Orthopyroxene [100], and Olivine $[100]$, dashed line $=$ trace of spinel foliation plane, [010], and [001] fabrics (see Cannat et al., this volume). Magnetic fabrics (susceptibility $=$ full symbols; ARM = half-full symbols; $\mathrm{SRM}=$ open symbols; maximum = square; intermediate $=$ triangle ; and minimum axes $=$ circle) and NRM direction (star). Stereographic projection $(\mathrm{V}=$ vertical direction and the same arbitrary reference mark as used for the petrographic and magnetic measurements).

determination of $\mathrm{T}_{\mathrm{c}}$ is the same as described in "Magnetic Properties of Basalts from Hole 648B" (Bina, this volume). All the Curie points correspond well to that of pure magnetite $\left(580^{\circ} \mathrm{C}\right)$. For two samples $(670 \mathrm{~A}-6 \mathrm{R}-1,30-32 \mathrm{~cm}$, and $670 \mathrm{~A}-$ $5 \mathrm{R}-2,102-104 \mathrm{~cm}$ ) the thermomagnetic curves were found to be irreversible (Fig. 4). In these cases, a large increase in $J_{s}$ occurs as a result of the heating, starting at least at temperatures as low as $300^{\circ} \mathrm{C}$ or so. This behavior may result from the conversion of nonstoichiometric phases to magnetite.
3. ARM was measured in a steady field $h=0.5$ Oe by stepwise increasing alternating field $\mathrm{H}$. By fitting a line to the linear part of the ARM curves versus $1 / \mathrm{H}$, saturation values of ARM are obtained (Table 2). Contrary to that was obtained for the basalts (see "Paleomagnetism of Basalts from Hole 648B" by Bina et al., this volume), the ARM intensities $\left(\mathrm{J}_{\mathrm{a}}\right)$ are much larger than NRM intensities $\left(J_{n}\right)$. This may be due to the presence of large magnetite grains, having low blocking field and low stability with time, which now weakly contribute to

Table 2. Magnetic parameters and Curie temperature of samples from Hole 670A.

\begin{tabular}{|c|c|c|c|c|c|c|c|c|c|c|c|c|c|c|}
\hline Sample & $\mathrm{J}_{\mathrm{n}}$ & I & $x$ & $Q$ & MDF & $\mathbf{J}_{\mathrm{a}}$ & $\mathbf{J}_{\mathrm{s}}$ & $\mathrm{J}_{\mathrm{rs}}$ & $\mathrm{H}_{\mathrm{c}}$ & $\mathrm{H}_{\mathrm{cr}}$ & $\mathrm{kp}$ & $\mathrm{J}_{\mathrm{rs}} / \mathrm{J}_{\mathrm{s}}$ & $\mathrm{H}_{\mathrm{cr}} / \mathrm{H}_{\mathrm{c}}$ & $\mathrm{T}_{\mathrm{c}}$ \\
\hline $3 W-1,12-14$ & 15.96 & 26 & 11.11 & 3.6 & 226 & 17.7 & 3.6 & 0.88 & 178 & 356 & 5 & 0.24 & 2 & - \\
\hline $5 \mathrm{R}-1,37-39$ & 12.83 & - & 40.62 & 0.79 & 68 & 29.2 & - & - & - & - & - & - & - & - \\
\hline $5 R-1,55-57$ & 45.02 & -12 & 34.55 & 3.25 & 37 & 57.4 & 5.6 & 0.32 & 53 & 153 & 2 & 0.07 & 2.9 & - \\
\hline 5R-1, 104-107 & 6.50 & - & 21.43 & 0.76 & 88 & 9.6 & - & - & - & - & - & - & - & - \\
\hline $5 \mathrm{R}-1,114-116$ & 9.52 & 66 & 32.58 & 0.73 & 65 & 17.6 & 6.4 & 0.31 & 50 & 168 & 4 & 0.05 & 3.4 & - \\
\hline $5 \mathrm{R}-1,134-136$ & 7.81 & 15 & 30.72 & 0.64 & 86 & 15.2 & 7.4 & 0.49 & 61 & 176 & - & 0.06 & 2.9 & 580 \\
\hline $5 R-2,5-7$ & 5.21 & - & 40.00 & 0.32 & 78 & 21.8 & 6.0 & 0.31 & 48 & 165 & 2 & 0.05 & 3.4 & 580 \\
\hline $5 \mathrm{R}-2,32-34$ & 23.62 & - & 10.48 & 5.63 & 37 & 12.1 & 2.3 & 0.23 & 95 & 280 & $i$ & 0.10 & 2.9 & 580 \\
\hline SR-2. 55-57 & 9.30 & -8 & 41.09 & 0.56 & 57 & 14.3 & 5.5 & 0.31 & 50 & 161 & 4 & 0.05 & 3.2 & 580 \\
\hline $5 R-2,102-104$ & 1.86 & 7 & 3.3 & 1.41 & 175 & 5.1 & 0.6 & 0.11 & 128 & 273 & 2 & 0.18 & 2.1 & 580 \\
\hline $6 \mathrm{R}-1,4-6$ & 0.25 & 12 & 1.19 & 0.52 & 85 & 2.0 & 0.2 & 0.04 & 107 & 228 & 1.5 & 0.20 & 2.1 & - \\
\hline $6 \mathrm{R}-1,30-34$ & 2.30 & - & 3.43 & 1.68 & 71 & 4.4 & 0.4 & 0.07 & 122 & 276 & 2 & 0.15 & 2.2 & 580 \\
\hline $7 R-1,42-43$ & 13.22 & - & 28.59 & 1.15 & 74 & 16.0 & 4.8 & 0.20 & 53 & 193 & 4 & 0.04 & 3.6 & - \\
\hline $8 \mathrm{R}-1,31-34$ & 2.22 & 50 & 4.51 & 1.23 & 106 & 6.2 & 0.7 & 0.12 & 120 & 271 & 2 & 0.15 & 2.2 & - \\
\hline $9 \mathrm{R}-1,12-14$ & 13.96 & - & 36.08 & 0.97 & 73 & 45.5 & 5.9 & 0.58 & 88 & 208 & 5 & 0.10 & 2.4 & - \\
\hline
\end{tabular}

Note: $\mathrm{J}_{\mathrm{n}}=$ intensity of $\mathrm{NRM}$ in $10^{-4} \mathrm{emu} / \mathrm{g} ; \mathrm{I}=$ inclination in degrees; $\chi=$ susceptibility in $10^{-4} \mathrm{emu} / \mathrm{g}$ Oe; Q $=\mathrm{Koenigsberger}$ ratio; $\mathrm{MDF}=$ median demagnetizing field in Oe; $\mathrm{J}_{\mathrm{a}}=\mathrm{ARM}$ intensity in $10^{-4} \mathrm{emu} / \mathrm{g} ; \mathrm{J}_{\mathrm{s}}, \mathrm{Jrs}=$ induced and remanent saturation magnetization in $\mathrm{emu} / \mathrm{g} ; \mathrm{H}_{\mathrm{c}}, \mathrm{H}_{\mathrm{cr}}=$ coercive and remanent coercive force in Oe; $\mathrm{kp}=$ paramagnetic susceptibility in $10^{-5}$ emu/g Oe; $\mathrm{T}_{\mathrm{c}}=$ Curie temperature in ${ }^{\circ} \mathrm{C}$ 

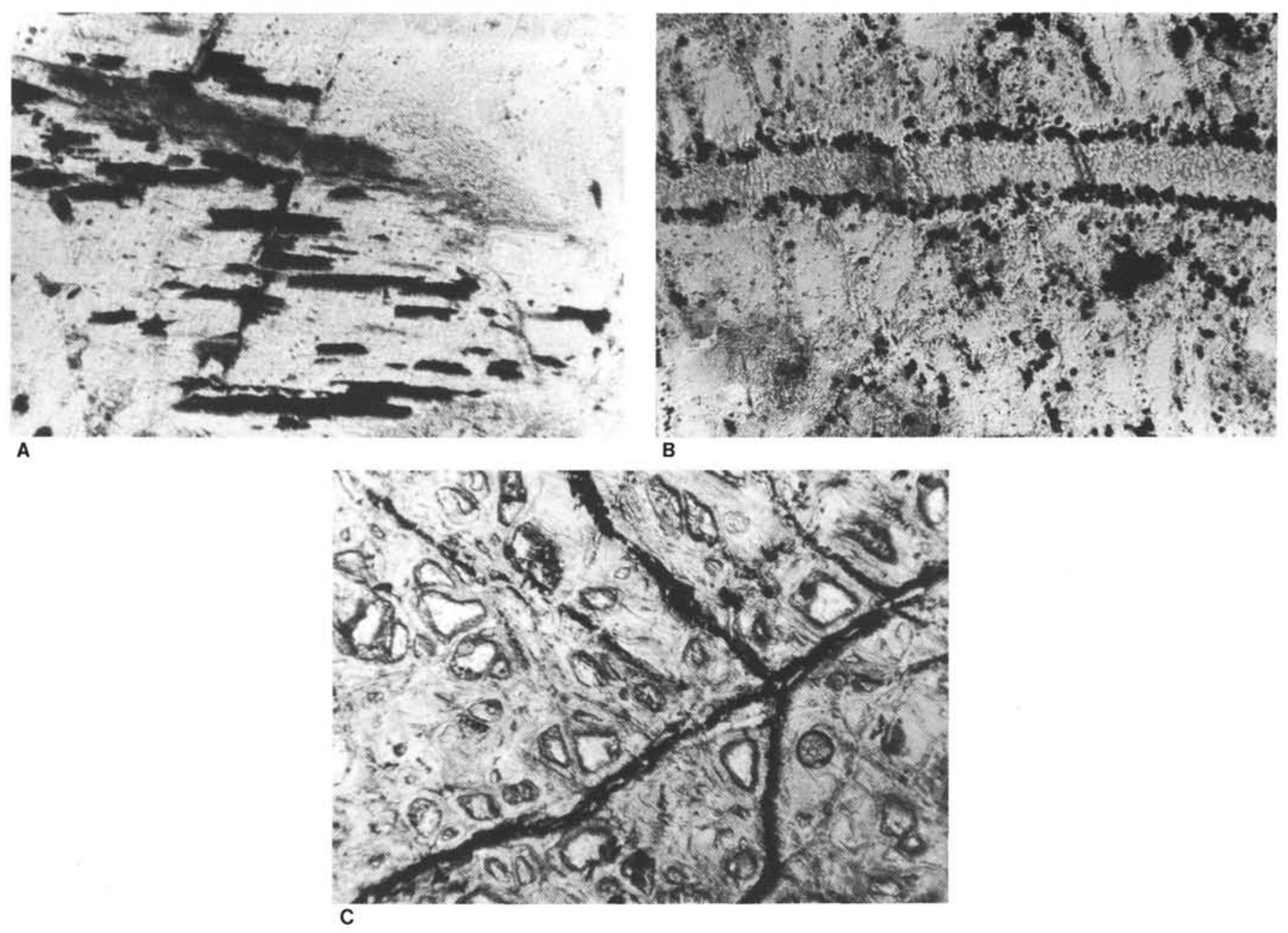

Figure 2. Thin sections of serpentinized peridotites. A, C. Sample 670A-5R-2, 19-21 cm. B. Sample 670 A-5R-1, 116-118 cm. Observed in transmitted natural light: magnetite within $\mathbf{A}$ or around $\mathbf{B}$ previous minerals, or forming veins. C. Lengths of the photograph diagonal are $1 \mathrm{~mm}$ for $\mathbf{A}$ and $\mathbf{B}$, and $1.7 \mathrm{~mm}$ for $\mathbf{C}$.

$\mathrm{J}_{n}$, as mentioned above (the high value of the viscosity index) and/or to the existence of multicomponent magnetization in some samples (see paleomagnetism section of Hole $670 \mathrm{~A})$

\section{CONCLUSION}

1. In the less serpentinized samples, the magnetic fabrics are rather mimetic of the high temperature deformation structure developed prior to serpentinization. The formation of magnetite veins, probably with large grain sizes, in more serpentinized peridotites, gave way to new magnetic fabrics, particularly for SRM anisotropy which seems here to be essentially related to such grains.

2. In the studied samples, the NRM is mainly CRM carried by magnetite as attested by the unique Curie temperature of $580^{\circ} \mathrm{C}$ observed in all the measured samples. From hysteresis parameters and $\mathrm{MDF}_{\mathrm{n}}$, one can suggest that the magnetic grains should be large MD for highly serpentinized samples and PSD for the samples with a low degree of serpentinization.

\section{ACKNOWLEDGMENTS}

We are grateful to M. Prévot for critical reading of the manuscript, to Mme. F. Calza for Curie temperature measurements, and to R. Enkin for English clarifications of the text. This research was partially supported by ODP France.

\section{REFERENCES}

Biquand, D., 1982. Infidélité palomagnétique observe dans une formation lacustre varve quaternaire dite "argiles d'Eybens (Grenoble, France)", Can. J. Earth Sci., 19:1196-1217.

Cann, R. J., 1979. Metamorphism in the ocean crust. In Deep Drilling Results in the Atlantic Ocean: Ocean Crust,: Maurice Ewing ser., Washington (Am. Geophys. Union), 2:232-238.

Daly, L., 1970. Etude des propérités magnétiques des roches métamorphiques ou simplement tectonisés. Nature de leur aimantation naturelle. Détermination de leur anisotropie magnétique et application l'analyse structurale. [Ph.D. dissert.] Univ. Paris.

Daly, L., and Formont, R., 1969. Détermination des faibles anisotropies magnétiques des roches et autres matériaux par la méthode du pendule de torsion. C. R. Acad. Sci. Paris, D, 268:473-476.

Daly, L., and Zinsser, H., 1973. Etude comparative des anisotropies de susceptibilité et d'aimantation rémanente isotherme. Conséquences pour l'analyse structurale et le palomagnétisme. Ann. Géophys., 29:189-200.

Dunlop, D. J., and Prévot, M., 1982. Magnetic properties and opaque mineralogy of drilled submarine intrusive rocks. Geophys. J. R. Astron. Soc., 69:763-802.

Francis, T.J.G., 1981. Serpentinization faults and their role in the tectonics of slow spreading ridges. J. Geophys. Res., 86:11616-11622.

Graham, J. W., 1954. Magnetic susceptibility anisotropy: an unexploited element of petrofabric. Geol. Soc. America Bull., 65:1257-1258.

Hrouda, F., 1982. Magnetic anisotropy of rocks and its application in geology and geophysics. Geophys. Surveys, 5:37-82. 
(a)

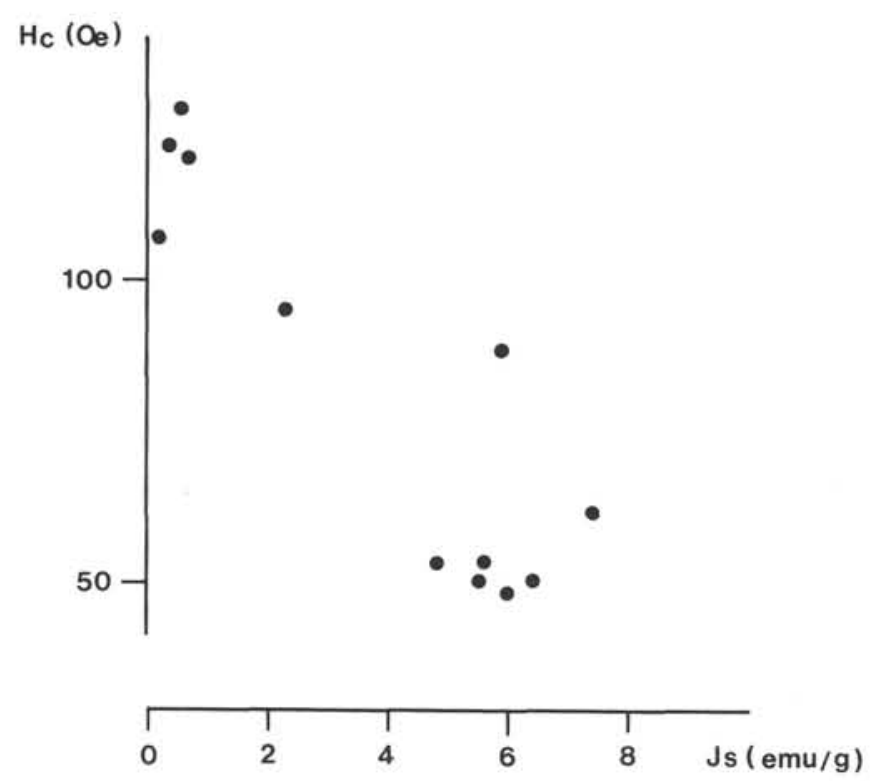

Figure 3. Relation between $\mathrm{J}_{\mathrm{s}}$ (denoted here as the degree of serpentinization) and coercive force $\mathrm{H}_{\mathrm{c}}$ (grain size dependent parameter). Sample $670 \mathrm{~A}-3 \mathrm{~W}-1,12-14 \mathrm{~cm}$, may contain both families of fine and coarse grains (a).

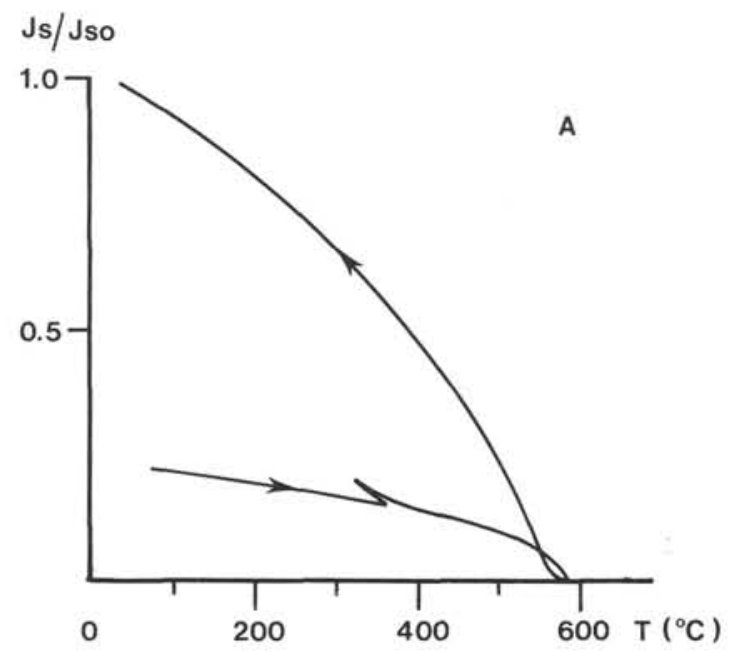

King, J., Banerjee, S. K., Marvin, J., and Ozdemir, O., 1982. A comparison of different methods for determining the relative grain size of magnetite in natural sediments: some results from lake sediments. Earth Planet. Sci. Lett., 59:404-419.

MacCabe, C., Jackson, M., and Ellwood, B. B., 1985. Magnetic anisotropy in the Trenton limestone: Results of a new technique, anisotropy of anhysteretic susceptibility. Geophys. Res. Lett., 12:333-336.

MacDonald, W. D., and Ellwood, B. B., 1988. Magnetic fabric of peridotite with intersecting petrofabric surfaces, Tinaquillo, Venezuela. Phys. Earth Planet. Inter., 51:301-312.

Smith, G. M., and Banerjee, S. K., 1985. Magnetic properties of plutonic rocks from the central north Atlantic ocean. In Bougault, H., Cande, S. C., Brannon, J. C.,et al., Init. Rep. DSDP, 82, Washington (U.S. Govt. Printing Office), 377-383.

Thellier, E., and Thellier, O., 1959. Sur l'intensité du champ magnétique terrestre dans le passé historique et géologique. Ann. Géophys., 20:121-130.

Date of initial receipt: 21 January 1988

Date of acceptance: 19 December 1988

Ms 106/109B-153

Figure 4. Examples of irreversible and reversible thermomagnetic curves. A. Sample 670A-6R-1, 30-32 cm. B. Sample $670 \mathrm{~A}-5 \mathrm{R}-2,32-34 \mathrm{~cm}$.

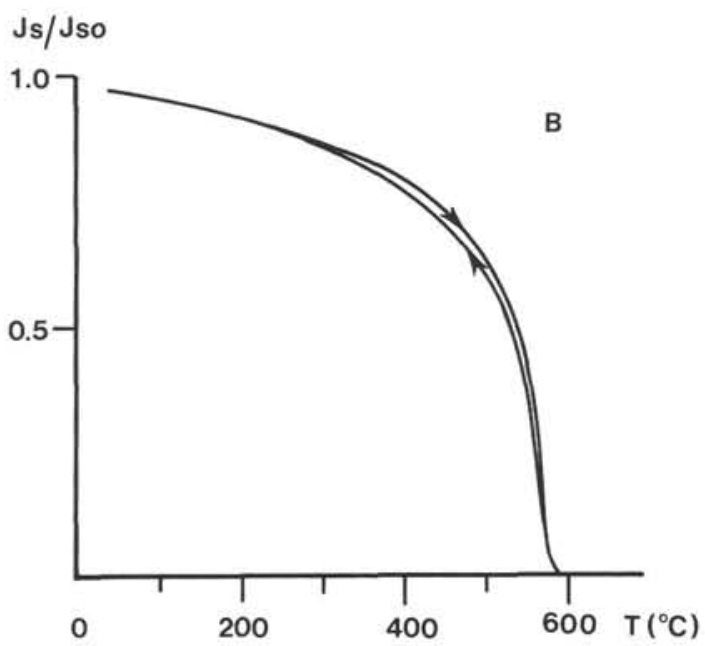

